UPPSALA UNIVERSITET
Working Paper 2007:10

Department of Economics

The equal division puzzle - empirical evidence on intergenerational transfers in Sweden

Henry Ohlsson 
Department of Economics

Uppsala University

P.O. Box 513

SE-751 20 Uppsala

Sweden

Fax: +46184711478
Working paper 2007:10

January 2007

ISSN 1653-6975

THE EQUAL DIVISION PUZZLE - EMPIRICAL EVIDENCE ON INTERGENERATIONAL TRANSFERS IN SWEDEN

Henry Ohlsson

Papers in the Working Paper Series are published on internet in PDF formats.

Download from http://www.nek.uu.se

or from S-WoPEC http://swopec.hhs.se/unnewp/ 


\title{
The equal division puzzle - empirical evidence on intergenerational transfers in Sweden*
}

\author{
Henry Ohlsson
}

29 January 2007

\begin{abstract}
The objective of this paper is to study to what extent parents divide their estates unequally between their children. Unequal sharing of parental transfers is, for example, a necessary condition for theories of altruistic (dynastic) behavior to hold. I use a new data set based on the estate reports for 230 widows, widowers, and divorcees from the city of Stockholm, Sweden deceased in 2004. Unequal sharing is unusual, depending on definitions only $7-25$ percent of the estates are unequally divided. The data set is also used to estimate probit models for the likelihood of unequal sharing. A first main result is that the probability of unequal sharing is increasing in the size of the estate. Second, the older the children are on average the more likely is unequal sharing. Finally, unequal sharing is more common among deceased from some neighborhoods of the city compared to deceased from other neighborhoods.
\end{abstract}

Keywords: bequests, inheritances, equal division, altruism

EconLit subject descriptors: C810, D100, D310, D910, H240

Correspondence: Henry Ohlsson, Department of Economics, Uppsala University, Box 513, SE-751 20 Uppsala, Sweden, email <henry.ohlsson@nek.uu.se>.

*I am grateful to Joakim Jonsson and Erik Ohlsson for excellent research assistance. Helpful comments and suggestions from Lennart Berg, Mats Johansson, Anders Klevmarken, Katarina Nordblom, and from seminar participants at Göteborg, Stockholm, Umeå, Växjö, and Statistics Sweden, Örebro are gratefully acknowledged. 


\section{Introduction}

This paper is about decisions that deceased parents made before they died. The objective is to study to what extent parents divide their estates unequally between their children. Unequal sharing of parental transfers, for example, is a necessary condition for theories of altruistic (dynastic) behavior to hold. ${ }^{1}$ Simple versions of altruistic models of intergenerational transfers predict that total transfers will be compensatory. Children with less economic resources will receive more transfers than siblings with more economic resources.

Understanding the determinants of parental property transfers is crucial for a wide range of economic issues. Some of these are the possible effects of fiscal policy, the determinants of savings and wealth, the equality of opportunity, and the optimal design of tax systems. In macroeconomics, for example, the Ricardian equivalence predictions about fiscal policy inefficiency, rest on the assumption of dynastic, altruistic, behavior.

Most empirical studies, however, find that unequal sharing of bequests is not very common. This has been viewed as a puzzle. Menchik (1980), Judge and Hrdy (1992), and Norton and Taylor, Jr. (2005) all study estate reports from different parts of the US. They report frequencies of unequal sharing in the interval $17-46$ percent. Tomes $(1981,1988)$ is the exception finding unequal division in 51-79 percent of the estates using a combination of estate reports and a survey. This was, however, questioned by Menchik (1988) who only found unequal sharing in 12-16 percent of the estates reports from the same time and place.

Using French estate data, Arrondel et al. (1997) report that 8 percent of the estates are unequally divided. Wilhelm (1996) uses US federal estate tax data where the frequency of unequal sharing is $23-31$ percent, while the corresponding frequency in a US survey based on twin register data used by Behrman and Rosenzweig (2004) is 8 percent.

An alternative source of information is survey data on the intended division of future bequests. Dunn and Phillips (1997), McGarry and Schoeni (1997), McGarry (1999), and Light and McGarry (2004) all use survey data of this type. They report unequal sharing frequencies in the interval 8 20 percent.

It is, however, an open question whether both bequests and inter vivos gifts will be compensatory in the altruistic models. The empirical findings are that inter vivos gifts, contrary to bequests, tend to be compensatory. This is a second puzzle. Is it possible to give a theoretical basis for why parents choose inter vivos gifts instead of bequests to make unequal transfers?

\footnotetext{
${ }^{1}$ The exchange model, introduced by Cox (1987), also predicts unequal sharing.
} 
Menchik (1988) and Wilhelm (1996) discuss that psychological costs may limit unequal transfers. Laitner (1997) suggests that social norms are important. But this does not explain why gifts instead of bequests are chosen. Lundholm and Ohlsson (2000) assume that gifts are private information while bequests are public information and that parents care about their reputation after death. Given these assumptions altruistic parents will choose compensatory gifts and equal bequests. Bernheim and Severinov (2003) also discuss theoretical models that generate results consistent with the empirical evidence. In their model bequests signal parental affection. Parents wish children to believe that they love them equally not to hurt their feelings.

I use a new data set based on the estate reports for 230 widows, widowers, and divorcees from the city of Stockholm, Sweden 2004. There are several advantages with this data set as compared to previously used data sets:

- The deceased's share of the estate can be separated from the estate share of a deceased spouse not previously transferred to heirs.

- Taxable gifts from the previous ten years and taxable life insurance payments are also included in the data.

- There is information on the family relationship of the donor and donee of each transfer. It is, therefore, possible to calculate the transfer to each family line.

The bequests from the deceased are unequally shared between the children in 13 percent of the cases. Adding the bequests to grandchildren, and great grandchildren in each family line to the bequests to children gives a frequency of unequal sharing of 20 percent. Adding taxable gifts and life insurance payments to the bequests increases these number to 16 percent and 23 percent. Total estates, also including the estate shares of deceased spouses not previously transferred to heirs, are unequally divided in 18 percent (children) and 25 percent (family lines) of the cases. Disregarding small variations from equal sharing by definition reduces the frequency of unequal sharing.

About 10 percent of the deceased have used a two generation equal sharing principle. A first part of the estate is shared equally between all children and a second part of the estate of shared equally among all grandchildren.

The data set is used to estimate probit models for the likelihood of unequal sharing. The three main results from the estimations are:

- The probability of unequal sharing is increasing in the size of the estate.

- The older the children are on average, the more likely is unequal sharing. 
- Unequal sharing is more common among deceased from some neighborhoods of the city compared to deceased from other neighborhoods.

The paper is structured as follows: I present data and descriptive facts about the deceased, the estates, and the heirs in Section 2. I also discuss how representative the sample is in this section. Section 3 presents the empirical evidence on unequal sharing. Section 4 concludes. An appendix provides additional descriptive statistics.

\section{Data and descriptive facts}

The number of inhabitants in the City of Stockholm, capital of Sweden, was 765,000 at the end of 2004. Slightly less than 7,500 inhabitants had died during that year.

I have, together with a research assistant, selected a sample from the Swedish Tax Authority's Inheritance Tax Register. This register has information on all estate reports of deceased in Sweden. ${ }^{2}$ Each file contains an estate report but also several other documents concerning the estate and the related transfers. When drawing the sample we have proceeded in the sequence:

1. deceased during 2004

2. registered in the City of Stockholm

3. there is a will

4. the estate is positive

5. there is no surviving spouse, the household is exiting (the deceased was a widow, widower, divorced, or unmarried)

6. the deceased has two or more children

A few comments: The wills can be of any type. Some stipulate unequal sharing, others stipulate that property received should be separate property. Many wills are joint and concern the property rights of a surviving spouse. Some wills are recent, others are old. ${ }^{3}$

A few cases when the actual taxable estate is zero but there are positive gifts and life insurance payments are included. There are also a couple of cases where there is a partner but no marriage.

There are 232 deceased people in the sample. Their estates are divided up in 820 lots. These lots are transferred to:

- 573 children, 10 of the children are, however, deceased

\footnotetext{
${ }^{2}$ It has been compulsory to file estate reports since 1734. The Tax Authority is responsible for keeping the register since 2001.

${ }^{3}$ Contrary to McGranahan (2006) I cannot, given the selection criterion that there is a will, study the determinants of will writing per se.
} 


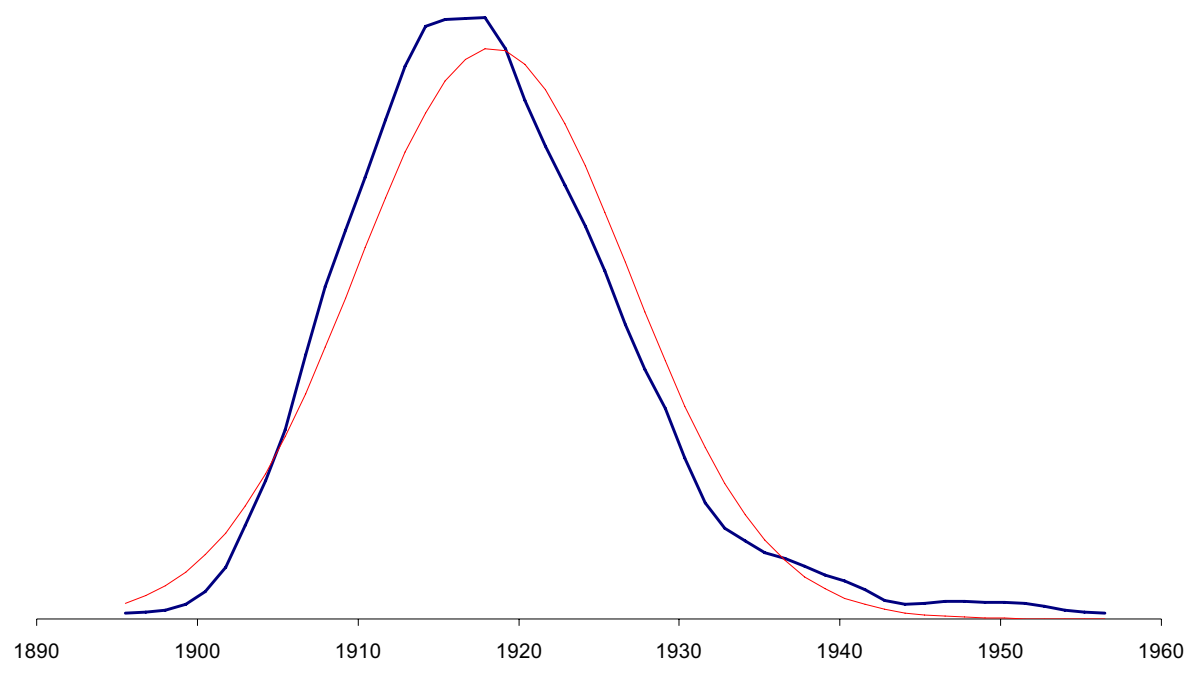

Figure 1: The distribution of parents' birth years.

- 176 grandchildren and great grandchildren, 17 of these are legal heirs because their parent is deceased

- 8 partners

- 45 relatives

- 11 other people

- 7 charities

This pattern of to whom transfers are made provide evidence for the proverb that blood is thicker than water! Very few lots go outside the family; to other people and charities. There is a considerable theoretical and empirical literature on charitable giving. But it is not possible to use this data set to contribute to this literature as charitable giving, contrary to in the US, is so rare in this sample.

\subsection{The parents and the estates}

The average age of the deceased parents was 85.7 years. ${ }^{4}$ Figure 1 shows the distribution of birth years for the parents. As is clear from the figure, the distribution is slightly skewed to the left. The thin line in the figure is a normal distribution with the same mean and spread.

\footnotetext{
${ }^{4}$ The descriptive statistics are summarized in an appendix.
} 
More than two thirds of the deceased parents, 69 percent, were women. Concerning marital status, 82 percent of the deceased parents were widow or widower, while 17 percent were divorced, while 1 percent were unmarried. Only 1 percent were foreign citizens.

The number of children of the deceased varies between 2 and 5 . Almost two thirds of the deceased, 63 percent, had two children. The average number of children is $2.48,1.15$ sons and 1.33 daughters. Most of the deceased, 43 percent, lived in the city center, 29 percent lived in the southern parts and 19 percent in the western parts.

Table 1 reports the basic facts about the estates. The average value of the estates of the deceased is almost SEK 1 million. ${ }^{5}$ Taxable gifts and life insurance add almost SEK 100,000 to this amounts. This is based on the tax values of the different assets and debts. The tax values are sometimes lower than the market values.

But the total estate might be larger than the estate of the deceased. This is because the bequest of a deceased spouse has not previously been transferred to the heirs. Instead these funds have been at the disposal of the surviving spouse for all economic choices except the bequest division. The reason for this arrangement might be a will by the deceased spouse or simply that the heirs did request to get their inheritances. The present law is that the estate of a deceased spouse always will be at the disposal of the surviving spouse even without a will.

The values of previously not transferred estates of deceased spouses are considerable, the total estates are almost SEK 1.4 million on average. In this case too, taxable gifts and life insurance add almost SEK 100,000 to this amounts.

The distributions of the different measures of the estates are very skewed. The medians are only half the means. The Gini-coefficients are all around 0.6. Figure 2 shows the distribution of the estate of the deceased (thin line) and the distribution of the total estate (thick line). ${ }^{6}$

The distribution of estates is, on the other hand, well approximated by a $\log$ normal distribution. Figure 3 compares the distribution of the logarithm of the estates with a normal distribution with the mean and spread. These wealth distributions for the deceased can be used to estimate the wealth distribution of the living. In many countries, wealth statistics are produced using estate multiplier methods using the estate values and mortality rates for different groups. Piketty et al. (2006) studies the long run evolution of wealth concentration in France using the estate multiplier method. ${ }^{7}$

The total assets in the estates were on average SEK 1,523,092 while total

\footnotetext{
${ }^{5}$ This corresponds to EUR 109,000; GBP 74,000; or USD 135,000 using the 2004 exchange rates of $9.13 \mathrm{SEK} / \mathrm{EUR}, 13.46 \mathrm{SEK} / \mathrm{GBP}$, and 7.35 SEK/USD.

${ }^{6}$ I have estimated the distributions using kdensity command in the Stata package.

${ }^{7}$ A century ago, Flodström used the estate distribution in Sweden 1908 to estimate the wealth distribution, see Finansdepartementet (1910, 14-34).
} 
Table 1: The estates and the inheritances, SEK.

\begin{tabular}{|c|c|c|c|c|c|c|}
\hline & mean & $\mathrm{P} 10$ & $\mathrm{P} 50$ & P90 & Gini & $\begin{array}{c}\text { standard } \\
\text { error }\end{array}$ \\
\hline \multicolumn{7}{|l|}{ the parents $(n=232)$ : } \\
\hline estate of the deceased & 991,836 & 137,196 & 518,917 & $1,794,660$ & .5911 & 2.634 \\
\hline $\begin{array}{l}\text { total transfer from the } \\
\text { deceased, incl. taxable } \\
\text { gifts and life insurance }\end{array}$ & $1,072,815$ & 140,298 & 561,080 & $2,236,065$ & .6021 & 2.872 \\
\hline total estate & $1,369,836$ & 167,120 & 687,002 & $2,391,270$ & .6091 & 3.669 \\
\hline $\begin{array}{l}\text { total transfer, } \\
\text { incl. taxable gifts } \\
\text { and life insurance }\end{array}$ & $1,479,896$ & 175,488 & 716,484 & $2,633,731$ & .6168 & 3.826 \\
\hline the children $(n=573)$ : & & & & & & \\
\hline inheritance from the deceased & 366,204 & 43,374 & 193,595 & 666,864 & .5918 & 2.080 \\
\hline $\begin{array}{l}\text { total transfer from the } \\
\text { deceased, incl. taxable } \\
\text { gifts and life insurance }\end{array}$ & 396,120 & 43,842 & 204,686 & 698,551 & .6062 & 2.254 \\
\hline total inheritance & 516,649 & 61,144 & 255,284 & 917,220 & .6132 & 2.776 \\
\hline $\begin{array}{l}\text { total transfer, } \\
\text { incl. taxable gifts } \\
\text { and life insurance }\end{array}$ & 558,316 & 63,291 & 258,894 & $1,007,950$ & .6214 & 2.892 \\
\hline
\end{tabular}




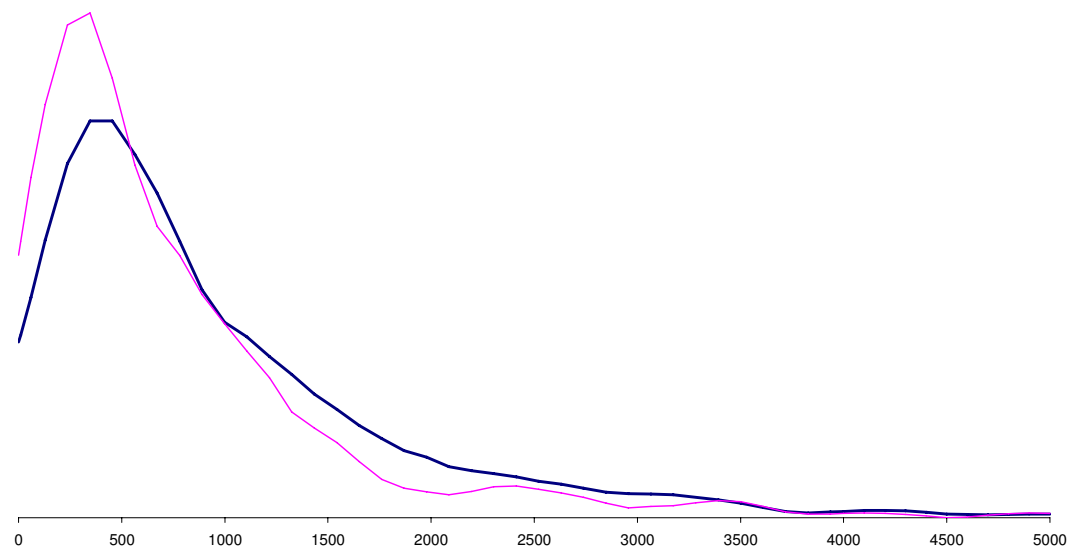

Figure 2: The distributions of the estate of the deceased (thin line) and the total estate (thick line).

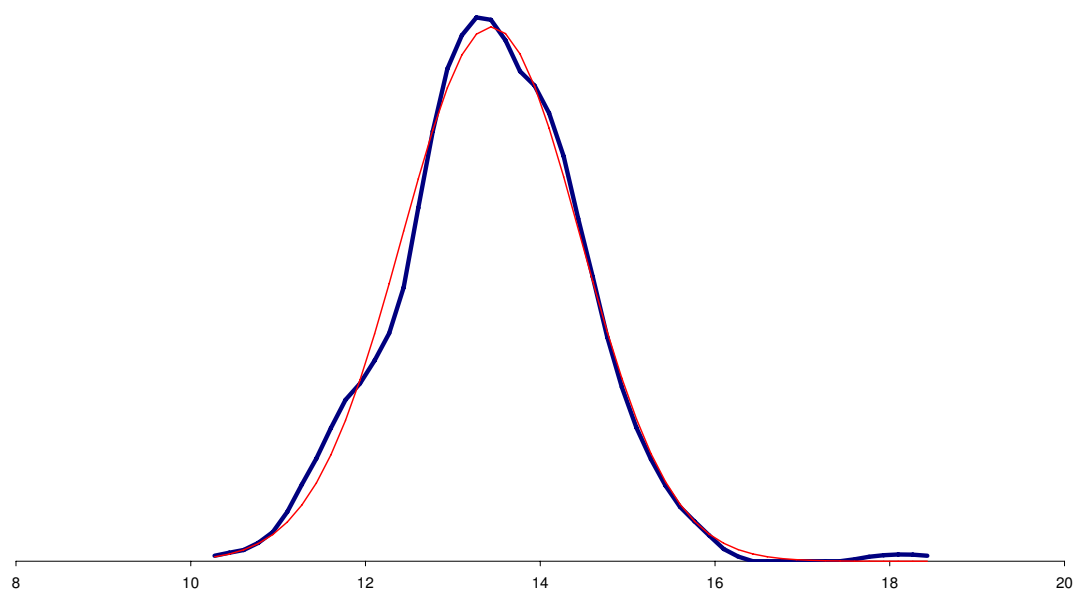

Figure 3: The distribution of the logarithm of the total estate. 
Table 2: Comparison with the living, individual data.

\begin{tabular}{|c|c|c|c|}
\hline & SEK 1,000 & $\begin{array}{c}\text { median } \\
\text { SEK 1,000 }\end{array}$ & $\begin{array}{c}\text { share of } \\
\text { gross wealth, } \\
\%\end{array}$ \\
\hline \multicolumn{4}{|l|}{ this sample } \\
\hline the estate of the deceased & 992 & 519 & 84.3 \\
\hline \multicolumn{4}{|c|}{ the Swedish Wealth Survey 2004} \\
\hline the city of Stockholm & 691 & n.a. & 68.2 \\
\hline the whole country & 494 & 102 & 68.2 \\
\hline $75+$ in the whole country & 735 & 315 & 95.3 \\
\hline
\end{tabular}

debts were SEK 154,112. The debt share of the deceased was 15.7 percent on average. The value of financial assets was considerably higher than the value of real assets, on average SEK 1,306,221 compared to SEK 216,872. Therefore, the share of financial assets was on average 87.8 percent.

\subsection{How representative is the sample?}

It is an important question how representative the present sample is. One might suspect that restricting the sample to people who have written wills and have more than one child will lead to a wealthier sample than the overall population.

Berg (2006) has used the Swedish Wealth Survey 2004 to calculate wealth in each municipality in the country. Average individual wealth in Stockholm was SEK 690,000, see Table 2. This considerably higher than the average for the whole country. The mean in the present sample is, however, more than 50 percent higher than the Stockholm average. One reason is that the present sample has less debt than the Stockholm average. It is also possible to compare the present sample with the average for old people in the country. The average wealth of people older than 75 years was SEK 735,000.

I also have access to a data set for all estates registered in 2003. This gives an opportunity to illustrative how representative my sample is. The average total estate in Sweden was SEK 380,000 in 2003, this is considerably lower than the mean in my sample, see Table 3 . Another way to illustrate this is that the median in my sample equals the 83rd percentile in the 2003 data. 
Table 3: Comparison with all estates 2003.

\begin{tabular}{|c|c|c|c|c|c|c|c|c|c|c|c|c|c|c|}
\hline sample & $\mathrm{n}$ of obs & mean & P10 & P50 & P90 & P99 & Gini & $\begin{array}{l}\text { standard } \\
\text { error }\end{array}$ & P10/P50 & P90/P50 & $\begin{array}{r}\text { this sample } \\
\text { P10 }\end{array}$ & $\begin{array}{r}\text { this sample } \\
\text { P50 }\end{array}$ & $\begin{array}{r}\text { average } \\
\text { age }\end{array}$ & $\begin{array}{l}\text { women } \\
\text { percent }\end{array}$ \\
\hline Sweden & 93,094 & 381,189 & 0 & 133,353 & $1,000,797$ & $2,810,228$ & 6987 & 5.836 & 0 & 7.505 & P54 & P83 & 79.8 & 51.2 \\
\hline Stockholm area & 16,660 & 472,906 & 0 & 114,070 & $1,362,442$ & $3,826,259$ & .7334 & 2.184 & 0 & 11.944 & P55 & P78 & 78.8 & 52.4 \\
\hline $\begin{array}{l}\text { Stockholm area, } \\
\text { positive estate }\end{array}$ & 11,719 & 672,294 & 28,894 & 324,482 & $1,667,341$ & $4,241,662$ & 6209 & 1.749 & .089 & 5.138 & P36 & P 69 & 81.4 & 53.6 \\
\hline $\begin{array}{l}\text { Stockholm area, } \\
\text { positive estate, } \\
\text { not married }\end{array}$ & 7,606 & 459,294 & 20,765 & 191,810 & $1,183,816$ & $3,302,845$ & .6458 & 1.797 & .108 & 6.172 & P 47 & P80 & 83.2 & 65.7 \\
\hline $\begin{array}{l}\text { Stockholm area, } \\
\text { positive estate, } \\
\text { not married, } \\
2 \text { or more children }\end{array}$ & 3,469 & 418,271 & 20,368 & 175,357 & $1,085,808$ & $2,916,728$ & .6328 & 1.746 & .116 & 6.192 & P49 & $\mathrm{P} 81$ & 83.9 & 66.2 \\
\hline $\begin{array}{l}\text { Stockholm area, } \\
\text { positive estate, } \\
\text { not married, } \\
2 \text { or more children, } \\
60+\text { years old }\end{array}$ & 3,320 & 418,001 & 20,428 & 174,794 & $1,085,358$ & $2,854,070$ & .6384 & 1.757 & .117 & 6.209 & P49 & P81 & 85.3 & 67.5 \\
\hline $\begin{array}{l}\text { this sample, } \\
\text { total estate }\end{array}$ & 232 & $1,369,836$ & 167,120 & 687,002 & $2,391,270$ & $6,881,532$ & .6091 & 3.669 & .243 & 3.481 & P10 & P50 & 85.7 & 69.4 \\
\hline
\end{tabular}




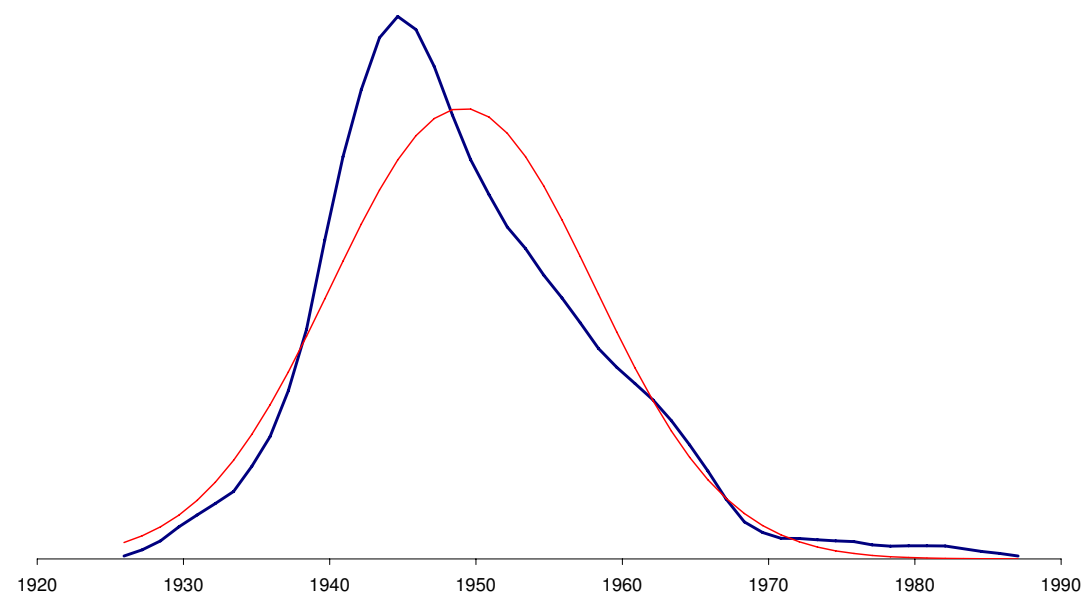

Figure 4: The distribution of children's birth years.

The table restricts the 2003 data step by step to become as similar as possible to my sample. The mean for positive estates in the Stockholm area of not married deceased 60 years and older with two or more children is SEK 420,000. The 10th percentile of my sample is almost at the median of the restricted 2003 sample, while the median in my sample is at the 81st percentile of the restricted 2003 sample.

How common are wills? My estimate is that my sample of estates with wills is approximately 15 percent of all estates fulfilling all other selection criteria. The number of deceased in the city of Stockholm as a share of the total number of deceased in the Stockholm area is 47 percent. This suggest that the number of positive estates in the city of Stockholm of not married deceased with two or more children is $0.47 * 3,469=1,630$. The 232 estates in my sample is 14.3 percent of the estimated 1,630 .

\subsection{The children and the inheritances}

The average age of the children is 54.9 years. Figure 4 shows the distribution of birth years for the children. As is clear from the figure, the distribution is skewed to the left, and more so than the distribution of birth years for parents. The thin line in the figure is a normal distribution with the same mean and spread.

Women are in majority among the children, 53 percent. 3 percent of the children are twins. Concerning marital status, 58 percent of the children are married, while 20 percent are divorced, 18 percent are unmarried, and 
2 percent are widow or widower.

The number of grandchildren varies between 0 and 7. More than four out of ten children, 42 percent, have two children of their own. The average number of children is 1.95, 1.02 sons and 0.92 daughters. Many of the children, 19 percent, live in the city center, 13 percent live in the southern parts and 11 percent in the western parts. 15 percent live in neighboring municipalities to the south of Stockholm and the same share lives in neighboring municipalities to the north, while 20 percent of the children live in the rest of the country and 7 percent live abroad.

The lower part of Table 1 reports the basic facts about the inheritances. The average value of the inheritance from the deceased is SEK 365,000, while the total inheritance is SEK 510,000 on average. Taxable gifts and life insurance add almost SEK 40,000 to these amounts. The distributions of the different measures of the inheritances are very skewed. The medians are only half the means.

\section{Empirical evidence}

\subsection{Frequency of unequal sharing}

Equal sharing of estate among the family lines of legal heirs is the legal default in Sweden. The civil law, moreover, stipulates that half the estate should be equally shared between legal heirs. The other half of the estate can be freely bequeathed.

It is possible to calculate several different measures of equal sharing using the present data set. A first issue to decide is which transfers to include. There are four obvious alternatives: inheritances from the deceased, total transfers from the deceased, total inheritances from both parents, and total transfers from both parents.

A second issue is which people to include. Are we interested in equal sharing between the children to the deceased? Does this also include heirs to deceased children? This is one possibility. But is also possible to include bequests to grandchildren and great grandchildren and study how the total bequest is divided between family lines.

A third issue is to decide how much the share may differ before the sharing is considered to be unequal. Table 4 shows how the degree of unequal sharing differs depending on the three choices. Suppose that we restrict the measure to the bequests from the deceased, only look at the children, and allow for a variation up to \pm 5 percent without considering the sharing to be unequal. Then sharing is unequal in only 7.3 percent of the cases in the present example. But if we instead look at total transfers to complete family lines and include all cases with deviations from exact equal sharing, then sharing is unequal in one out of four cases. 
Table 4: Frequency of unequal sharing, percent.

\begin{tabular}{|c|c|c|c|c|c|c|}
\hline & $\begin{array}{l}\text { defini } \\
\text { exact }\end{array}$ & $\begin{array}{r}\text { childr } \\
\text { (legal h } \\
\text { of of eq } \\
\pm 1 \% \\
\end{array}$ & $\begin{array}{l}\text { sharing: } \\
\pm 5 \%\end{array}$ & $\begin{array}{l}\text { defini } \\
\text { exact }\end{array}$ & $\begin{array}{l}\text { of oq } \\
\pm 1 \% \\
\end{array}$ & $\begin{array}{l}\text { sharing: } \\
\pm 5 \%\end{array}$ \\
\hline bequests from the deceased & 13.3 & 8.6 & 7.3 & 19.8 & 16.4 & 14.2 \\
\hline $\begin{array}{l}\text { total transfers from the deceased, } \\
\text { incl. taxable gifts and life insurance }\end{array}$ & 16.4 & 11.6 & 9.5 & 22.8 & 19.8 & 16.8 \\
\hline total bequests & 14.2 & 9.9 & 8.6 & 20.7 & 17.7 & 15.1 \\
\hline $\begin{array}{l}\text { total transfers, } \\
\text { incl. taxable gifts and life insurance }\end{array}$ & 18.5 & 14.7 & 11.2 & 25.0 & 22.8 & 18.1 \\
\hline
\end{tabular}

Gifts are unequally shared. There are taxable gifts in reported in connection to 28 estates. These gifts are unequally shared in 60 percent of the cases. It should be noted that taxable gifts are public information in the same way as bequests are. On the contrary, there are life insurance payments associated with 13 estates. These payments are equally shared in all cases.

Many of the deceased have written wills using a two generation equal sharing principle. By this I refer to the situation when a first part of the estate is shared equally between children and a second part of the estate of shared equally among grandchildren. This can be viewed as an attempt strike a balance between "vertical" balance between generations and "horizontal" balance between different family lines. It implies equal sharing between family lines if the number of grandchildren is the same in all family lines. But if the number of grandchildren differs between family lines sharing will be unequal when measured as deviations between family lines. Therefore, the two generation equal sharing principle is compensatory in the sense that it compensates for family size but it does not compensate for other economic variables

There are bequests to grandchildren by wills in 34 estates in this sample. The share of total bequests to children and grandchildren going to the latter is 32.4 percent on average, see Table 5 . The upper limit for this share is 50 percent because of the civil law.

The number of these estates that has a part that is equally shared between children is 20 , while 21 estates have a part that is equally shared between grandchildren. This is if we use an exact definition equal sharing. Using wider definitions of equal sharing by definition increases these numbers.

The two generation equal sharing principle is used in 16 estates. The 
Table 5: Two generation equal sharing.

average estate share

$\mathrm{n}$ of estates grandchildren, percent

$\begin{array}{lcc}\begin{array}{l}\text { all estates with bequests } \\ \text { to grandchildren }\end{array} & 34.4 \\ & & \\ \text { equal sharing, children } & & 37.8 \\ \text { exact } & 20 & 32.8 \\ \pm 1 \% & 27 & 32.6 \\ \pm 5 \% & 29 & \\ & & \\ \text { equal sharing, grandchildren } & & 33.7 \\ \text { exact } & 21 & 34.2 \\ \pm 1 \% & 24 & \\ \pm 5 \% & 24 & 37.6 \\ & & 34.1 \\ \text { two generation equal sharing } & & 34.8 \\ \text { exact } & 16 & \\ \pm 1 \% & 20 & \\ \pm 5 \% & 21 & \end{array}$

share of total bequests to children and grandchildren going to the latter is 37.6 percent on average. Allowing 5 percent variation increases the number of estates divided according to the two generation principle to 21 .

\subsection{Probability of unequal sharing}

Table 6 reports the results from estimations of probit models for unequal sharing. I try twelve different definitions of unequal sharing as dependent variable: three types of transfers, children and family lines, and an exact and a wide definition of equal sharing.

The likelihood of unequal sharing is increasing in the total amount transferred in most specifications. Judge and Hrdy (1992), Table 8, find the same, while the wealth variables are not significant in the estimations reported by McGarry (1999), Table 5. It lies close at hand to expect that parents find less of a point to divide an estate unequally if the total estate is small.

Men and women are as likely to divide unequally. Divorcees are more likely to divide unequally in one specification. Having more than two children does not seem to affect the probability of unequal sharing. 
Table 6: Unequal sharing, probit models, marginal effects.

bequests from the deceased total transfers from the deceased

children family lines $\quad$ children family lines

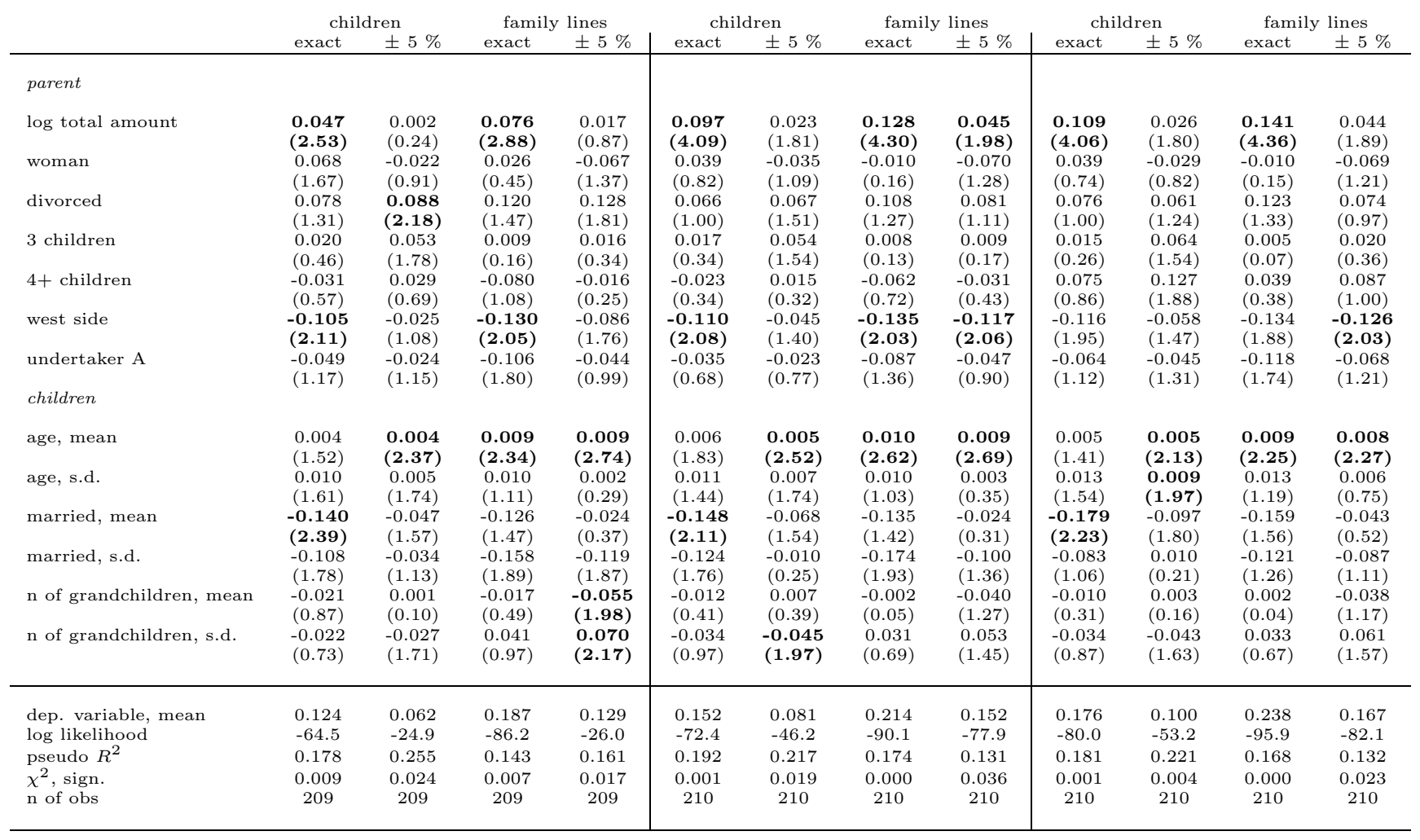


I find significant neighborhood effects in most specifications. Deceased who lived in the west side of the city are less likely to divide unequally compared to those who lived in the city center and the south side. Average income 2004 for inhabitants $65+$ in the west side was lower than for those living in the city center. And the political parties to left got a higher share of the votes in the local election 2002 in the west side than in the city center. But average income 2004 was even lower for those living in the south side, and the vote share for the left parties was even higher there.

There is also information on who did the filing of the estate report to the Tax Authority. This is sometimes done by the children but often done by undertakers, banks, or legal firms. A big chain of undertakers has filed for about 25 percent in the sample (I label it undertaker A). In some specifications, the estates filed by this chain are less likely to be shared unequally at the 10 percent significance level. The estate filers might have been advising the deceased when the will was written.

The specifications also include several exogenous variables for the children. I try both the means and the standard deviations for each group of siblings.

The older the children are on average the more likely is unequal sharing in most specification. In some specifications, unequal sharing is more likely at the 10 percent significance level when siblings differ more in age. These results are similar to those reported by McGarry (1999), Table 5. This can be interpreted as that the older the children are, the more information the parent has about the economic resources the children have.

There are also some indications that the probability of unequal sharing is lower if more children are married. The number of grandchildren does not, on the other hand, seem to affect unequal sharing.

Table 7 reports the results from estimations of probit models for two generation unequal sharing. I try an exact and a wide definition of two generation equal sharing as dependent variable. The reference category is all estates of deceases who have grandchildren but have not used the two generation unequal sharing principle.

The estimation results are similar to those reported in Table 6. A higher total amount increases the probability of two generation equal sharing. The probability becomes higher, the older the children are on average.

\section{Concluding remarks}

The objective of this paper is to study to what extent parents divide their estates unequally between their children. Unequal sharing of parental transfers is a necessary condition for theories of altruistic (dynastic) behavior to hold. I use a new data set based on the estate reports for 230 widows, widowers, and divorcees from the city of Stockholm, Sweden 2004. The sample 
Table 7: Two generation equal sharing, probit models, marginal effects.

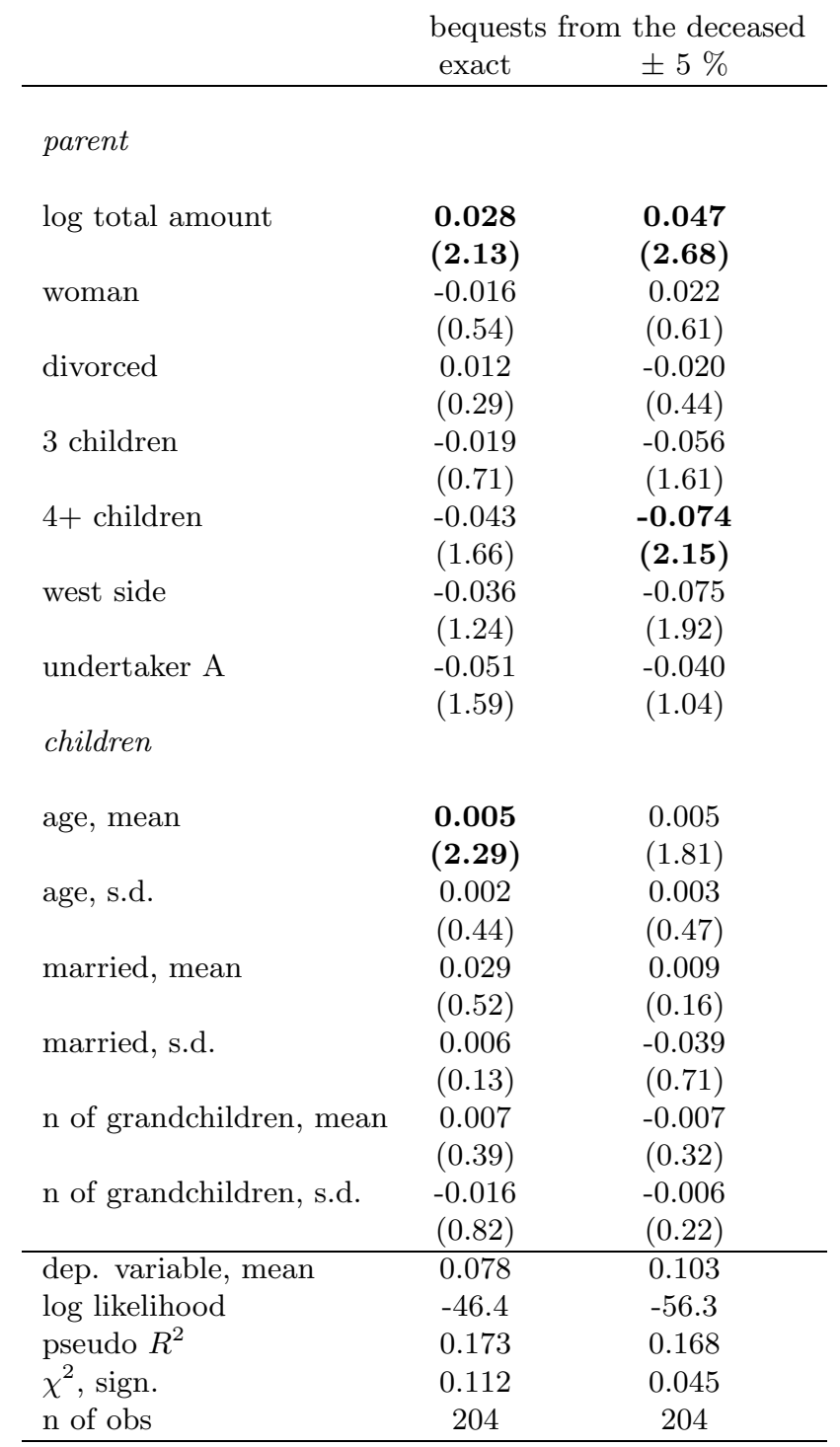


is wealthy, most belong to the three upper deciles in the wealth distribution of deceased. The data are very detailed, a gain that has been traded off against the small sample size.

Unequal sharing is unusual, depending on definitions only $7-25$ percent of the estates are unequally divided. This is similar to what has been found in most empirical studies using US data.

The data set is also used to estimate probit models for the likelihood of unequal sharing. A first main result is that the probability of unequal sharing is increasing in the size of the estate. Second, the older the children are on average the more likely is unequal sharing. These results are in line with what other studies have found. Finally, unequal sharing is more common among deceased from some neighborhoods of the city compared to deceased from other neighborhoods.

Do these results falsify the predictions of altruistic models and exchange models? Not necessarily. It has only been possible for me to include taxable gifts during ten years before death. The deceased might have given to their children earlier, nontaxable amounts, and unreported amounts. 


\section{Appendix: Descriptive statistics}

Table 8: Descriptive statistics.

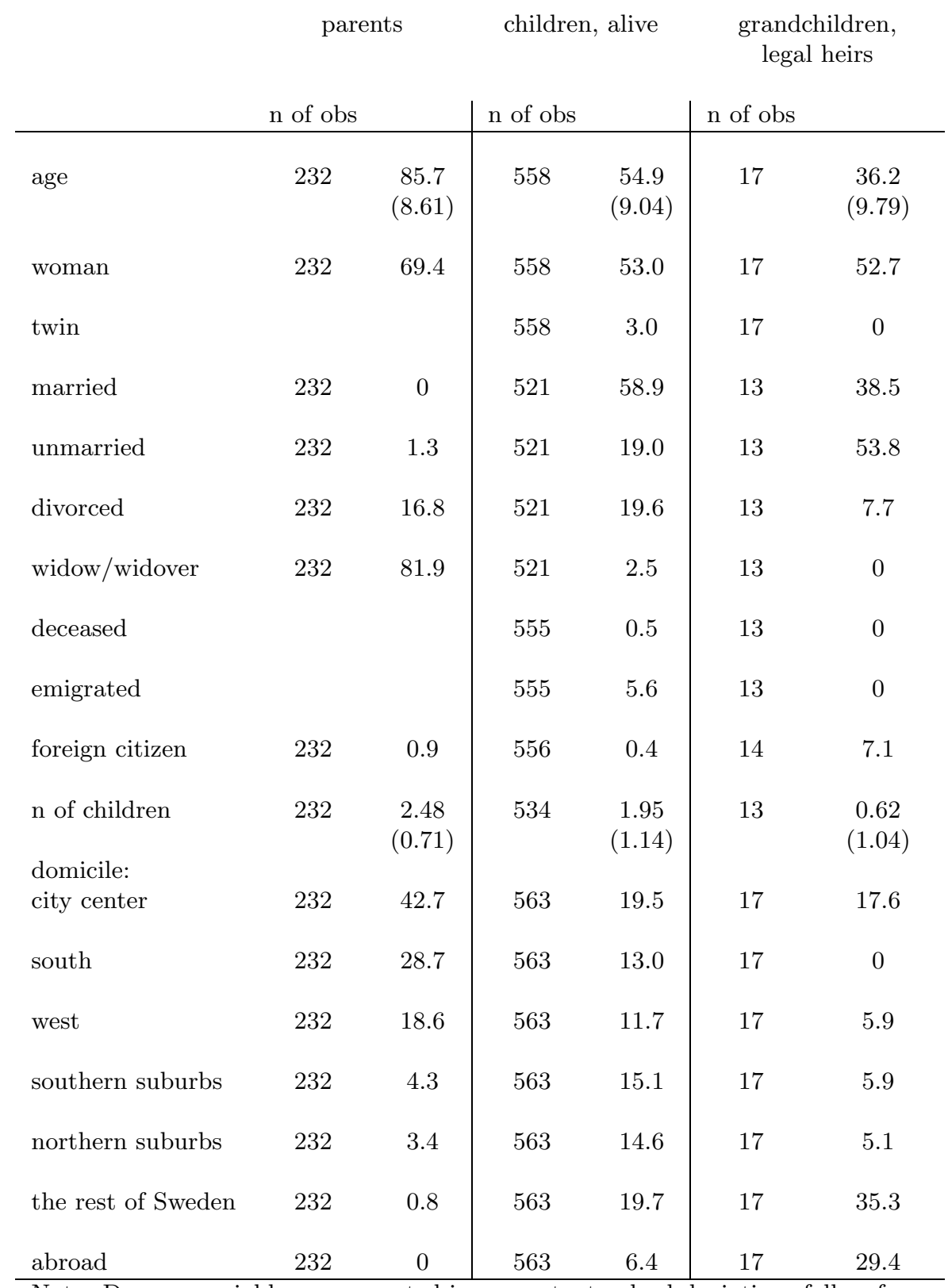

Note. Dummy variables are reported in percent, standard deviations follow from the means. Standard deviations are reported for the two continuous variables. 


\section{References}

Arrondel, L., Masson, A., and Pestieau, P. (1997). Bequest and inheritance: Empirical issues and France-U.S. comparison. In Erreygers, G. and Vandevelde, T., editors, Is Inheritance Legitimate? Ethical and Economic Aspects of Wealth Transfers, chapter 4, pages 89-125. Springer Verlag, Berlin.

Behrman, J. R. and Rosenzweig, M. R. (2004). Parental allocation to children: New evidence on bequest differences among siblings. Review of Economics and Statistics, 86(2):637-640.

Berg, L. (2006). Förmögenhetskällan: De svenska hushållens förmögenhetsutveckling. Rapport, Nordea, Stockholm.

Bernheim, B. D. and Severinov, S. (2003). Bequests as signals: An explanation for the equal division puzzle. Journal of Political Economy, 111(4):733-764.

Cox, D. (1987). Motives for private income transfers. Journal of Political Economy, 95(3):508-546.

Dunn, T. A. and Phillips, J. W. (1997). The timing and division of parental transfers to children. Economics Letters, 54(2):135-137.

Finansdepartementet (1910). Bouppteckningar efter aflidna, inregistrerade vid vederbörande domstolar åren 1906-1908, volume 3 of Finansstatistiska utredningar. K. Finansdepartementet, Stockholm.

Judge, D. S. and Hrdy, S. B. (1992). Allocation of accumulated resources among close kin: Inheritance in Sacramento, California, 1890-1984. Ethology and Sociobiology, 13(5-6):495-522.

Laitner, J. (1997). Intergenerational and interhousehold economic links. In Rosenzweig, M. R. and Stark, O., editors, Handbook of Population and Family Economics, volume 1A, chapter 5, pages 189-238. North-Holland, Amsterdam.

Light, A. and McGarry, K. (2004). Why parents play favorites: Explanations for unequal bequests. American Economic Review, 94(5):1669-1681.

Lundholm, M. and Ohlsson, H. (2000). Post mortem reputation, compensatory gifts and equal bequests. Economics Letters, 68(2):165-171.

McGarry, K. (1999). Inter vivos transfers and intended bequests. Journal of Public Economics, 73(3):321-351. 
McGarry, K. and Schoeni, R. F. (1997). Transfer behavior within the family: Results from the Asset and Health Dynamics Survey. Journals of Gerontology, 52B(Special issue):82-92.

McGranahan, L. (2006). Will writing and bequest motive: Early 20th century Irish evidence. Working Paper 2006-18, Federal Reserve Bank of Chicago.

Menchik, P. L. (1980). Primogeniture, equal sharing and the U.S. distribution of wealth. Quarterly Journal of Economics, 94(2):299-316.

Menchik, P. L. (1988). Unequal estate division: Is it altrusim, reverse bequests, or simply noice? In Kessler, D. and Masson, A., editors, Modelling the Accumulation and Distribution of Wealth, chapter 4, pages 105-116. Clarendon Press, Oxford.

Norton, E. C. and Taylor, Jr., D. H. (2005). Equal division of estates and the exchange motive. Journal of Aging and Social Policy, 17(1):63-82.

Piketty, T., Postel-Vinay, G., and Rosenthal, J.-L. (2006). Wealth concentration in a developing economy: Paris and France, 1807-1994. American Economic Review, 96(1):236-256.

Tomes, N. (1981). The family, inheritance, and the intergenerational transmission of inequality. Journal of Political Economy, 89(5):928-958.

Tomes, N. (1988). Inheritance and inequality within the family: Equal division among unequals, or do the poor get more? In Kessler, D. and Masson, A., editors, Modelling the Accumulation and Distribution of Wealth, chapter 3, pages 79-104. Clarendon Press, Oxford.

Wilhelm, M. O. (1996). Bequest behavior and the effect of heirs' earnings: Testing the altruistic model of bequests. American Economic Review, 86(4):874-892. 
WORKING PAPERS*

Editor: Nils Gottfries

2006:9 David Kjellberg, Measuring Expectations. 46pp.

2006:10 Nikolay Angelov, Modellig firm mergers as a roommate problem. 21pp.

2006:11 Nikolay Angelov, Structural breaks in iron-ore prices: The impact of the 1973 oil crisis. 41pp.

2006:12 Per Engström and Bertil Holmlund, Tax Evasion and Self-Employment in a High-Tax Country: Evidence from Sweden. 16pp.

2006:13 Matias Eklöf and Daniel Hallberg, Estimating retirement behavior with special early retirement offers. 38pp.

2006:14 Daniel Hallberg, Cross-national differences in income poverty among Europe's 50+. 24pp.

2006:15 Magnus Gustavsson and Pär Österholm, Does Unemployment Hysteresis Equal Employment Hysteresis? 27pp.

2006:16 Jie Chen, Housing Wealth and Aggregate Consumption in Sweden. 52pp.

2006:17 Bertil Holmlund, Quian Liu and Oskar Nordström Skans, Mind the Gap? Estimating the Effects of Postponing Higher Education. 33pp.

2006:18 Oskar Nordström Skans, Per-Anders Edin and Bertil Holmlund, Wage Dispersion Between and Within Plants: Sweden 1985-2000. 57pp.

2006:19 Tobias Lindhe and Jan Södersten, The Equity Trap, the Cost of Capital and the Firm's Growth Path. 20pp.

2006:20 Annika Alexius and Peter Welz, Can a time-varying equilibrium real interest rate explain the excess sensitivity puzzle? 27pp.

2006:21 Erik Post, Foreign exchange market interventions as monetary policy. 34pp.

2006:22 Karin Edmark and Hanna Ågren, Identifying Strategic Interactions in Swedish Local Income Tax Policies. 36pp.

2006:23 Martin Ågren, Does Oil Price Uncertainty Transmit to Stock Markets? 29pp.

2006:24 Martin Ågren, Prospect Theory and Higher Moments. 31pp.

2006:25 Matz Dahlberg, Eva Mörk, Jørn Rattsø and Hanna Ågren, Using a discontinuous grant rule to idenitfy the effect of grants on local taxes and spending. 26pp.

\footnotetext{
* A list of papers in this series from earlier years will be sent on request by the department.
} 
2006:26 Jukka Pirttiläa and Håkan Selin, How Successful is the Dual Income Tax? Evidence from the Finnish Tax Reform of 1993. 40pp.

2006:27 Henrik Jordahl and Che-Yuan Liang, Merged Municipalities, Higher Debt: On Free-riding and the Common Pool Problem in Politics. 34pp.

2006:28 Per Engström, Ann-Sofie Kolm and Che-Yuan Liang, Maternal Addiction to Parental Leave. 18pp.

2006:29 Jonas Björnerstedt and Andreas Westermark, Delay in Bargaining with Externalities. 27pp.

2006:30 Pär Österholm, Incorporating Judgement in Fan Charts. 36pp.

2006:31 Mikael Carlsson and Andreas Westermark, Monetary Policy and Staggered Wage Bargaining when Prices are Sticky. 26pp.

2007:1 Mikael Elinder, Local Economies and General Elections. 26pp.

2007:2 Ouarda Merrouche, The Long Term Impact of French Settlement on Education in Algeria. 19pp.

2007:3 Ouarda Merrouche, The Long Term Effect of Education Spending Decentralization on Human Capital in Spain. 15pp.

2007:4 Erik Post, Macroeconomic imbalances and exchange rate regime shifts. 38pp.

2007:5 Christian Andersson, Teacher density and student achievement in Swedish compulsory schools. 31pp.

2007:6 Thomas Aronsson, Sören Blomquist and Luca Micheletto, Where Should the Elderly Live and Who Should Pay for their Care? A Study in Demographics and Geographical Economics. 22pp.

2007:7 Sören Blomquist and Vidar Christiansen, Public Provision of Private Goods and Nondistortionary Marginal Tax Rates. 17pp.

2007:8 Marcus Eliason and Henry Ohlsson, Living to Save Taxes. 13pp.

2007:9 Åsa Ahlin and Eva Mörk, Effects of decentralization on school resources: Sweden 1989-2002. 31pp.

2007:10 Henry Ohlsson, The equal division puzzle - empirical evidence on intergenerational transfers in Sweden. 20pp.

See also working papers published by the Office of Labour Market Policy Evaluation http://www.ifau.se/ 